\title{
Accounting Outsourcing and Firm Performance in Iranian SMEs
}

\author{
Yahya Kamyabi (Corresponding author) \\ Faculty of Business \& Accountancy, University of Malaya \\ 50603 Lembah Pantai, Kuala Lumpur, Malaysia \\ Tel: 60-17-282-1350 E-mail: ykamyabi344s@yahoo.com
}

Susela Devi $(\mathrm{PhD})$

Faculty of Business \& Accountancy, University of Malaya

50603 Lembah Pantai, Kuala Lumpur, Malaysia

Received: January 10, 2011

Accepted: January 25, 2011

doi:10.5539/ijef.v3n4p181

\begin{abstract}
The aim of this study is to examine the factors that influence on outsourcing of accounting functions and the effect of outsourcing on firm performance in Iranian manufacturing small and medium enterprises (SMEs). Results from a survey of 658 SMEs show that outsourcing is positively associated with owner/manager knowledge and the technical competence, but was not found a positive relationship between outsourcing and the size of the firm. It was found that outsourcing has a positive impact on SME performance. In addition, our analysis suggested that outsourcing did not mediate the influence of firm size on SME performance but partially mediated the impact of owner/manager knowledge on firm performance and also technical competence of an accountant on SME performance.
\end{abstract}

Keywords: Outsourcing, external accountants, SMEs, Performance, Resource-based theory (RBT), Transaction cost economics theory (TCE)

\section{Introduction}

The role of small and medium enterprise (SMEs) in a national economy has been accentuated all over the world as to their contribution to the total productivity and job opportunities (Gunasekaran et al, 1999). In particular, in developing countries, SMEs play a significant role (IFAC, 2006). For example, SMEs comprise ninety percent of all enterprises in Iran (Bayati and Taghavi, 2007; UNIDO, 2003). In fact, they have a significant role in the development of the country (Bayati and Taghavi, 2007).Therefore, there is a potential to improve SME performance (Gunasekaran et al, 1999).

Nowadays with increasing competitive pressures, smaller firms have to diminish their costs and create new opportunities through optimized utilizing of external resources (Mahmoodzadeh et al., 2009). Indeed, most of SMEs has a tendency to fail because lack of planning, knowledge, absence of overall managerial skills, competencies and capabilities (Dyer and Ross, 2008). By relying on outsourcing, SMEs can obtain the capabilities and competences they require from external service providers (Gilley et al., 2004). Consequently, the presence of outsourcing practices has provided an option for SME survival (Jayabalan et al., 2009). In fact, activities in which the companies lack the necessary resources or capabilities internally can be outsourced (McIvor, 2009). On the whole, transaction cost economics (TCE) theory would indicate that outsourcing by smaller firms should create lower costs (e.g. employment, payroll and training) than when those functions are performed in-house because smaller firms lack of competences that result from scale and experience effects (Gilley et al., 2004). In addition, the resource-based theory (RBT) states that the limited capabilities and competences of smaller firms make it essential for them to obtain resources from external sources (Hadjimanolis, 2000). Hence, RBT can also assist with analyzing SME capabilities, which can link outsourcing with performance (McIvor, 2009). Further, TCE can enhance our understanding of whether it is more suitable to insource or outsource a function (Stratman, 2008).

Today, accounting functions are perceived to have significant roles in SME environment, but most SMEs face problem in dealing with their accounting tasks (Jayabalan et al., 2009). For instance, SMEs lack of expertise and accounting knowledge because the accounting functions (tasks) not only require knowledge of generally-accepted accounting rules, but also need that one knows how to utilize the rules in a company environment (Marriott and Marriott 2000; Everaert et al., 2006). In fact, accounting functions outsourcing is an opportunity for SMEs so as to sustain a competitive benefit in the business environment as outsourcing could reduce the burden suffered by SMEs 
(Jayabalan et al., 2009). Because most of SMEs lack of sufficient resource to permit accounting functions to be conducted in house (Doing and Gooderham, 2005). Therefore, there are several reasons that show SMEs more vulnerable than larger firms (Gooderham et al, 2004). Indeed, in large part this vulnerability is RBT in the sense that SMEs lack the necessary competencies for survival (Gooderham et al, 2004). Hence, external accountants can aid SMEs operating in a dynamic and competitive environment, to incorporate operational considerations within long-term strategic plans (Ismail and King, 2005). For example, external accountants perform a number of roles in the SME community: they not only offer accounting services but also prepare advisory services upon a variety of broader business management issues (Marlow and Carter, 2005).

Outsourcing is an influential vehicle to diminish costs and increase performance (McIvor, 2009; Everaert et al., 2007; Gilley et al., 2004). For example, accounts payable outsourcing reduces the administrative costs and cost saving without capital investment (Jayabalan et al., 2009). Furthermore, profitability of the firm can be enhanced by outsourcing in several ways, including: (1) employment, (2) capabilities, (3) facilities and (4) payroll (Jiang et al., 2006). For instance, as outsourcing increases, costs will shrink, and investment in facilities, and manpower can be reduced (Jiang et al., 2006). Moreover, outsourcing of accounting services can add value through the higher quality available from external sources, in particular external accountants (Gilley et al., 2004). For example, SME lack of expertise and accounting knowledge to carry out accounting functions internally (Jayabalan et al, 2009; Everaert et al., 2007). Therefore, better performance may be obtained by outsourcing (Gilley et al., 2004). On the one hand, by outsourcing human resources to external sources, firms may achieve superior levels of employee performance and productivity, thus leading to higher financial performance (Gilley et al., 2004). On the other hand, by outsourcing functions or tasks, SMEs would be able to focus on the value-creating functions that drive competitive benefit (Gilley and Rasheed, 2000). Hence, outsourcing of services enables a firm's capabilities to be improved by better performance (Shang et al, 2008). Therefore, a major concern of the RBT is how a firm's capabilities develop and affect its performance (McIvor, 2009). In actual fact, the outsourcing decision is influenced by the ability of an enterprise to invest in developing a capability and sustaining a superior performance position in the capability corresponding to competitors (McIvor, 2009).

While there has been research of outsourcing effects on performance in general, no empirical research has particularly addressed outsourcing effects of accounting functions on SME performance, but only limited studies examined the effect of the advisory services of external accountants on SME performance (Berry et al. 2006; Bennett and Robson 1999). In addition, research in SME context with respect to outsourcing of accounting functions is growing (Everaert et al., 2010; Everaert et al., 2007; Doran, 2006; Carey et al., 2006), but less research conducted in developing countries while they overlook the link of outsourcing to SME performance (Jayabalan et al,. 2009). Furthermore, empirical evidence from studies on developed countries may not be as relevant to developing countries such as Iran (Mashayekhi and Mashayekh, 2008). In fact, the nature of accounting functions are people-intensive and SMEs lack people and capability or competence, so this study provides comprehensive actions plans to garner the existing capabilities of professional accountants in serving the SME community. Therefore, research is needed to determine how accountants can help the Iranian SMEs in achieving their potential as contributors to society and the economic welfare of countries. Therefore, this study has attempted to shed light on the factors influence on outsourcing, and the link of the outsourcing to firm performance by applying resource-based theory (RBT) and transaction cost economics (TCE) theory using a sample of Iranian manufacturing SMEs. Consequently, the key questions can be stated as: what are the factors that determine whether an Iranian SME outsource accounting functions, and whether the firm involved in outsourcing lead to improve performance?

The rest of the discussion is arranged as follows: Section 2 provides the background of study and develops hypotheses utilizing the resource based theory (RBT) and transaction cost economics theory (TCE) to guide the framework to investigate the outsourcing of accounting functions. Section 3 explains the research methodology. Section 4 presents the findings and discussions the implications thereon. Section 5 concludes with suggestions for future research.

\section{Literature review}

\subsection{Outsourcing}

Outsourcing is usually explained as the contracting with an external party to provide services or activities that could be provided by an internal source (Carey et al., 2006). On one hand, the process of outsourcing involves the 'external accountant,' including both the professional accountant and the accounting firm (Everaert et al, 2010). On the other hand, the process of internalizing involves the 'in-house accountant' who is the company staff member performing the accounting functions in the SME (Everaert et al, 2010).

\subsection{Professional accountants in Iranian SMEs}

After privatization in 1991, financial reporting has gained significance in Iranian businesses regarding international 
pressures from the World Bank and the International Monetary Fund regarding privatization (Mashayekhi and Mashayekh, 2008; Mirshekary and Saudagaran, 2005).Therefore, the need for financial information and auditing the accounts of companies has been enhanced after privatization of economic entities (Mirshekary and Saudagaran, 2005; Salehi and Azary, 2008). To satisfy this need, the Iranian Association of Certified Public Accountants (IACPA) was established in 2001 as an independent professional body (Mirshekary and Saudagaran, 2005). Professional accountants play a significant role in Iranian economy; this is more significant for SMEs because they constitute over ninety percent of enterprises of Iran (Mirshekary and Saudagaran, 2005).

\subsection{Accounting functions in SMEs}

Kirby et al. (1998) distinguish statutory services from non-statutory services in the SME environment. They reported that external accountants were the most likely source of "non statutory services. For example, Stanger (2004) found that external accountants are generally the most used source of professional services for small firms. It may be observed that external accountants were a very significant source of professional services (Berry et al., 2006). Gooderham et al. (2004) investigate factors associated with small firms relying on their external accountant as a business advisor and they suggested that most small firms rely on their external accountant as business advisor. Furthermore, Sian and Roberts (2009) found 57.2 percent of small firms outsourced accounting services including financial statements (51.1 per cent), tax or VAT information (30.8 percent) and accounting system (18.1 percent). For example, Jayabalan et al. (2009) found the types of accounting functions outsourced based the standard functions which include bookkeeping, accounts receivable, accounts payable, financial reporting, management reporting and tax filing. Moreover, Everaert et al. (2007) revealed that more than half of SMEs use a combination of outsourcing and insourcing of accounting functions, while 35 percent of the SMEs use only in-house accountants' services and 12 percent use total outsourcing of accounting services. In the UK, Berry et al. (2006) found 85 percent of small enterprises used their external accountant as a source of advice. In the UK and Canada, Blackburn et al. (2006) report that SMEs use accountants more than any other single source as their main provider of advice in relation to dealing with their regulatory obligations. In Australia, Carey et al. (2005) found 67 percent of SMEs use external accountants as a source of professional services and also indicate that there is room for external accountants to enhance the amount of advisory services to SMEs. Whilst these studies discussed above have been conducted in more developed countries, literature on role of professional accountants in emerging economies or lesser developed economies such as Iran is absent except a limited research (Jayabalan et al., 2009).

\section{Theoretical framework and hypotheses}

Two important theories can influence on outsourcing are transaction cost economics (TCE) theory and the resource-based theory (RBT) of the firm (McIvor, 2009). These two theories are concentrating on two different issues. For example, TCE discusses why companies exist whereas RBT argues that why firms vary in performance; these two issues are extremely significant to the outsourcing decision (McIvor, 2009). The TCE indicates the functions that are not company-specific should be outsourced, while the RBT suggests that functions not significant to core competencies must be outsourced (Gilley et al., 2004). In general, concentrating on and developing certain capabilities is central to the RBT that indicate what functions (tasks) should be conducted in-house and what ought to be outsourced (McIvor, 2009).

The RBT is important to the study of outsourcing, as superior performance attained in enterprise activities corresponding to competitors would explain why such tasks are carried out in-house (McIvor, 2009). Specifically, TCE theory has been utilized in explaining the outsourcing decision in areas such as outsourcing of accounting functions (Everaert et al., 2010), internal audit activities (Carey et al., 2006) and human resource (HR) (Gilley et al., 2004). Firm size may include transaction costs through economies of scale whereby SMEs are shown to have lower frequency of activities than larger enterprises (Carey et al., 2006). Accordingly, smaller companies have larger difficulty in producing economies of scale, which in turn is likely to reduce the justification for adopting internal facilities and increase outsourcing alternatives (Carey et al., 2006). Similarly, the RBT suggests that smaller firms outsource accounting functions to broaden its market (Marriott et al 2008). In addition, in SME environment, RBT is useful in number of studies on outsourcing of accounting functions and provides constructive basis upon which to consider the factors that determine the tendency of a firm to outsource accounting tasks (Marriott et al, 2008, Johnson et al, 2007; Everaert et al., 2006; Doving \& Gooderham, 2005; Gooderham et al, 2004; Bennett and Robson, 2003). Therefore, RBT leads to suppose that the SMEs make use of external accountants as a source of professional services and such services will be a function of the resources at the disposal of the firm (Gooderham et al, 2004).

\subsection{Owner/manager knowledge}

The RBT explains that SMEs are lack of knowledge to perform the accounting functions internally (Everaert et al., 2006). For example, in accounting, a resource shortage means that the firm is lacking in terms of knowledge to carry 
out the accounting tasks (Jayabalan et al., 2009). This is particularly applicable for SMEs, since resource constraints generally are much more significant for SMEs than they are for large firms (Marriott and Marriott, 2000). For example, SMEs are lacking accounting knowledge to perform accounting functions, so they are more likely to outsource their accounting tasks to external accountants (Everaert et al., 2006, 2007, 2010). Correspondingly, Everaert et al. (2007) asserted that SMEs lack of necessary skills, whereas external accountants frequently are extremely specialized in this matter. In effect, external accountants are in a unique position to provide professional and accounting services such as systems analysis, design, and implementation and support advice to their clients (Breen et al, 2003).

However, asking for and receiving information and support services may imply that the SME owner/manager does not know enough about the area in which they seek information and, oftentimes, owner/managers are reluctant to make such an admission (Kamyabi and Devi, 2011). This may indicate that SME owner/managers are often not fully aware of the range of services currently available to them (Liddicoat and Stringer, 2005). Similarly, part of the reason may lie in the lack of sufficient requiring evidence of the benefits of obtaining such services (Watson, 2003). Sophisticated and capable SME owner/managers may understand the benefits of compensating for their own inadequate knowledge or skills by accessing external service provider (Watson, 2003). Hence, they may turn to external accountant for professional and accounting services and perhaps wider assistance (Berry et al., 2006). However, less sophisticated and incapable SME owner/managers may be unaware of their own weaknesses to reach out for help, believing they can do it all themselves (Watson, 2003). The predicted relationship is examined by means of the following hypothesis.

H1: Firms with owner/managers having high levels of knowledge in accounting will outsource accounting functions more than those firms that with owner/managers having low levels of knowledge.

\subsection{Technical Competence}

One of the objectives of the RBT is to help owner/managers to realize why competences can be perceived as a firms' most valuable asset and understand how those assets can be used to improve firm performance (Caldeira and Ward, 2003). SMEs outsource the functions that are not core competences, and concentrating on activities not included in the core competences can enhance firm performance (Gilley et al., 2004; Espino Rodríguez and Padrón-Robaina, 2004). Attributes of technical competence to an accountant include appropriate qualifications and experience, essential specialized skills, industry specialization and technological expertise (Carey et al., 2006). The largest parts of SME owner/managers have no professional, management and other formal qualifications (Kamyabi and Devi, 2011). Indeed, external accountants' services to their SMEs can summarize a range of competencies providing an important source of competitive benefit (Gooderham et al., 2004). One possible way for a smaller firm to obtain competencies is to utilize qualified persons (Gooderham et al, 2004). Therefore, by relying on outsourcing, smaller firms can obtain the competence they need from external service providers (Gilley et al., 2004). Moreover, the reliance by SMEs on external accountants is indicated to be a result of the perceptions of SMEs that external accountants are competent and able to provide a value-for money service in providing accounting services (Leung et al, 2008). Many of SME owner/managers lack financial skills and knowledge of how financial control systems might be utilized to aid decision-making (Deakins et al., 2001). For instance, the functions involved providing advisory services on internal planning, decision-making and control, that is, in areas where a SME owner/manager often lacks competence (Gooderham et al, 2004). Hence, SMEs rated very highly the technical competence of external accountants concerning regulation matters (Blackburn et al, 2006). It is predicted that perceptions of external accountants' technical competence will influence the decision to outsource accounting tasks (Carey et al., 2006). Consequently, the earlier arguments are summarized in the following hypothesis:

$\mathrm{H} 2$ : The stronger the perception that external accountants are more technically competent concerning the delivery of accounting activities than in-house accountants, the greater the propensity for outsourcing of accounting functions.

\subsection{Firm size}

The Firm size often ascertains the extent of its activities (Carey et al., 2006). RBT suggests that smaller firms seek accounting services to enhance their competitiveness as the firm extends its market (Marriott et al 2008). One important characteristic of smaller firms is that they rarely have the resource to allow accounting functions to be carried out in house (Doing and Gooderham, 2005). Therefore, RBT explained that the use of external support and professional services interacts with the size and age of the firm (Bennett and Robson, 2003). For instance, smaller and younger businesses are likely to have more limited internal resources than larger companies (Johnson et al., 2007). Consequently, small firms seek external assistance from accountants (Doing and Gooderham, 2005). In addition, TCE theory influences firm size via economies of scale whereby smaller firms are shown to have lower frequency of activities than larger enterprises (Carey et al., 2006). For example, smaller firms have greater difficulty 
to create economies of scale, and cannot have any justification for adopting in-house facilities and enhance outsourcing alternatives (Carey et al., 2006). Johnson et al. (2007) and Dyer and Ross (2008) suggest that the use of professional and support services positively associated with size of the firm . Conversely, Mohan-Neill (1995) indicated that younger and smaller firms utilize less market information when they make decisions. That is why the new and smaller firms have a limited financial and human resource, which makes collecting information a difficult task (Mohan-Neill, 1995). Although large firms might also benefit from the intrinsic efficiencies of an external accountant, the comparative benefit of the external accountant is probable to lessen as the firm size enhances because larger companies have greater capacity to get cost efficiencies via economies of scale from an in-house facilities (Carey et al., 2006). Therefore, based on the prior discussion, this study tests the following hypothesis.

H3: The smaller the firm, the greater the tendency for outsourcing of accounting functions.

\subsection{Firm performance}

The RBT theory is significant to outsourcing, as superior performance achieved in the company activities compared with competitors (McIvor, 2009). Besides, TCE theory suggests outsourcing by smaller enterprises generate lower costs (e.g. staffing and payroll) than when those functions are conducted internally because smaller companies lack of competences and experience effects (Gilley et al., 2004). Regarding the two theories, there are several ways in which such outsourcing positively affect on firm performance (Gilley et al., 2004). Outsourcing can produce cost reduction by decreasing investment in human resources (e.g. payroll, manpower) required to improve processes (Espino-Rodríguez and Padrón-Robaina, 2004). For instance, outsourcing provides the SMEs to have an expert and specialist on employees (staffs), and they do not pay for that expertise and without adding to their payroll (Jiang et al., 2006). In addition, by outsourcing activities, the firm will be better able to focus on the value-creating activities or core business that drive competitive benefit (Gilley et al., 2004). Consequently, SMEs will likely achieve higher levels of performance by outsourcing their functions to external service provider (Gilley et al., 2004).

Gilley et al. (2004) explained the association between outsourcing and firm performance, and concluded that outsourcing activities (e.g. payroll and training) had a significant positive influence on firm performance. In the same way, Espino Rodríguez and Padrón-Robaina (2004) found that outsourcing has a positive influence on the financial performance. Moreover, Jiang et al. (2006) found that outsourcing positively related to profitability of the firm. Besides, the significance of the role of external accountants, reported in most studies reviewed by Bennett and Robson (1999) and Berry et al. (2006) to examine the services of an external accountant and SME performance. Bennett and Robson (1999) demonstrate an association between SMEs that obtain the services of an external accountant and employment growth. In this study, SME respondents are placed into one of three growth categories: (i) declining/stable, (ii) medium growth, and (iii) fast growth. The percentage of SMEs that use external accountants' services was higher (fast growth category) than in the medium growth category and the declining/stable growth category. Hence, this study supports that the purchase of an external accountant's services is associated with SME growth. Berry et al. (2006) explored the relationship between the four types of advisory services provided by an external accountant and SME performance (growth). This study revealed that the average growth of users of the services of an external accountant was significantly higher than the average growth of non-users. Consequently, the previous arguments are summarized in the following hypothesis:

H4: A SME performance improves directly to the extent to which the outsourcing of accounting functions is utilized.

According to the above discussion, the owner/manager knowledge, technical competence and firm size are expected to influence outsourcing, which, in turn, influences firm performance. Stated in a different way, owner/manager knowledge, technical competence, firm size may be expected to positively and significantly influence firm performance via their positive influence on outsourcing. Hence, we hypothesize,

H 5: Outsourcing will mediate the relationship between (a) owner/ manager knowledge and firm performance, (b) technical competence and firm performance, and (c) firm size and firm performance, respectively.

The main associations predicted are shown in Figure 1.

\section{Method}

\subsection{Data collection}

According to prior studies as discussed earlier, we limited our survey population to companies in terms of number of employees in the range of less than 250 employees, while excluding micro-firms with fewer than 10 employees because micro enterprises hardly have any option between outsourcing and insourcing of accounting functions (Everaert et al, 2007). We utilised the Iran Small Industries \& Industrial Parks Organization (ISIPO) database (http://www.iraniec.ir), excluding services and public companies, and included only manufacturing sector SMEs 
fewer than 250 workers. This resulted in a population of 17,100 enterprises. Then, we selected a sample of 1750 manufacturing SMEs randomly, using a systematic probability method. A questionnaire survey was designed and developed based on prior studies, and then the questionnaires were sent to each SME owner/manager by post mail at 5 March 2010. Hence, we conducted two stages to collect data. In the first stage of the data collection, from 1750 questionnaires distributed, only twenty percent (350 questionnaires) were collected. Due to the low response rate, the second stage of data collection was conducted. Questionnaires with a reminder letter were sent again to those SME owner/managers who had not responded to the questionnaire survey. Another 420 responses were received, giving a total of 770 respondents. Nevertheless, 112 questionnaires were excluded because of the repeated or incomplete responses by the respondents. However, we finally had only 658 usable answers, representing an effective response rate of 38 percent. The response rate is very high in contrast to preceding research of SME context by Everaert et al. (2007) who obtained a low response rate (10 percent). In addition, based on suggestion by Armstrong and Overton (1997), we tested for response bias by examining the differences between the early and late respondents in terms of model variables, so we did not find any significant differences.

\subsection{Measurement of the variables}

\subsubsection{Owner/manager knowledge}

Owner/manager knowledge was measured using a 7-point scale $(1=$ no knowledge; $7=$ extensive knowledge $)$ developed by Ismail and King (2007). Based on this measurement, respondents were asked to indicate their knowledge level relating to financial and managerial accounting techniques, word processing, spreadsheet, database, accounting, e-mail, Internet and computer-assisted production management applications. This item scale exhibited a sufficiently high Cronbach's alpha $(\alpha=0.88)$.

\subsubsection{Technical competence}

Technical competence derived by Carey et al. (2006) including six items (Specialized industry wide knowledge, expertise in internal control, experience and qualifications, depth of understanding of your organization, expertise in computerized information systems (CIS) accounting and auditing, and expertise in risk management). Therefore, for measuring this variable, respondents were asked to indicate degree to which the firm perceives its external accountant as a technical competent source of accounting functions in each item, using 7-point Likert scale where $1=$ lowest score and $7=$ highest score. The measure of variable was displayed an adequately high Cronbach's alpha $(\alpha=0.91)$.

\subsubsection{Firm size}

For measuring firm size in this study, we used the number of employees developed by Audet and St-Jean (2007) and Doran, 2006). The participants are asked how many people work in the business. Respondents were provided with five categories.

\subsubsection{Outsourcing}

In this study, accounting functions (tasks) include bookkeeping works, preparation of financial statements, payroll accounting, budgeting /forecasting, customer profitability analysis, product costing, financial planning, financial management services, business strategy and planning, performance management, tax consultancy, business advice, management consultancy, financing advice and IT consultancy that a firm needs and are applicable in Iranian SME are similar to that derived from Everaert et al. (2007), Doran (2006). Hence, for measuring outsourcing of accounting functions, we used the measurement developed by Espino-Rodríguez and Padrón-Robaina, (2004) and Espino-Rodríguez et al. (2008), respondents were asked to indicate the level of outsourcing of the accounting tasks on a 7-point Likert type scale, with 1- not outsourced and 7-totally outsourced. The measure of outsourcing was found to have acceptable reliability in the sample (Cronbach's $\alpha=0.91$ ).

\subsubsection{Firm performance}

Firm Performance as dependent variable was previously tested and validated by Sarapaivanich and Kotey (2006). Thus, we first asked respondents to indicate the level of the importance attached to the four financial (profitability, growth in sales, return on assets and cash flow) and three non-financial (lifestyle, independence and job security) performance goals on a 7-point Likert type ranging from 1-not at all important to 7-very important. Then, respondents were asked to indicate their satisfaction with the seven financial and non-financial performance goals over the previous two financial years on a 7-point Likert type ranging from 1-strongly dissatisfied to 7-very satisfied. Each 'satisfaction' score was multiplied by the corresponding 'importance' scores to compute a weighted average performance index for each firm. The measure of performance was shown to have satisfactory reliability in the 
sample (Cronbach's $\alpha=0.98)$.

\section{Results}

\subsection{Descriptive statistics}

Our sample included 658 SME owner/managers, 79 percent male and 21 percent female. Most of the respondents were quite well educated, and 89 percent of them had a university graduate degree. For example, 87 percent of them had a university undergraduate degree and 13 percent postgraduate degree. The overall level of managerial experience was high with nearly three-fourth of respondents having over five years of experience, and 68 percent companies employed between 10-50 people, and 32 percent of the firms employed more than 50 people (less than 250). Moreover, Table1 demonstrates the descriptive statistics including the mean and standard deviation (S.D.) and correlations among the main variables. Thus, the results of a correlation analysis of the independent variables and dependent variable are presented in Table1. The correlation between variables was such that multicollinearity is not a concern.

\subsection{Hypotheses testing}

\subsubsection{Testing for direct effects}

Table2 shows regression coefficients and standard error (S.E) for each of the predictor variables. Adjusted $\mathrm{R}^{2}$ reveals that $23 \%$ of the variance of "outsourcing" is explained by the model 1 . According to the multiple linear regression analysis in table 2 (Model 1), owner/manager knowledge (H1) and technical competence (H2) were significantly associated with outsourcing (Coefficient $=.529, \mathrm{p}<0.001$; Coefficient $=.754, \mathrm{p}<0.001$ respectively). Hypotheses 1 and 2 were supported. Besides, in preparing for our regression analyses, we noted that size of the firm (H3) might be positively associated with outsourcing, but the results didn't support our prediction (Model 1). Indeed, firm size was unrelated to outsourcing (Coefficient $=-.489, \mathrm{p}=.483$ ). Thus, hypothesis 3 was not supported.

In addition, we conducted linear regression analysis in table 2 (Model 2) to test the outsourcing effect as the predictor variable on firm performance as the dependent variable. The results suggests that outsourcing has a significant impact on performance (Coefficient $=.317, \mathrm{p}<0.001$ ). Therefore, it also should be noted that outsourcing of accounting functions is significantly associated with firm performance. Hence, the data supports hypothesis 4 .

\subsubsection{Testing for mediation effects}

To test for the mediation effect of outsourcing on the relationship between independent variables (owner/manager knowledge, technical competence and firm size in this study) and firm performance, we utilized the conditions that recommended by Baron and Kenny (1986). The conditions are: first, the independent variables must have a significant effect on the mediator variable (Outsourcing). Second, the independent variables must be shown to influence the dependent variable (firm performance) in a regression of the independent variable on the dependent variable. Third, the mediator variable must affect the dependent variable in a regression of both the independent variables and the mediator variable on the dependent variable. If the above conditions keep in the predicted direction, then the effect of the independent variables (owner/manager knowledge, technical competence and firm size) on the dependent variable (firm performance) in third regression equation should be less than in second regression equation to create mediation effect. Therefore, the results of above discussions are shown in table 3 .

Results of multiple regression analyses in Table 3 (Model 1) show that two independent variables; owner/manager knowledge and technical competence were significantly associated with outsourcing $(\mathrm{p}<0.001)$. This complies with condition (1) suggested by Baron and Kenny (1986), but we didn't find any significant association between firm size and outsourcing (Coefficient $=-.489, \mathrm{p}=.483$ ). Condition (2) is also satisfied as owner/manager knowledge and technical competence $(\mathrm{p}<0.001)$ are positively and significantly associated with firm performance, but size of the firm negatively related to firm performance (Coefficient $=-2.311, \mathrm{p}<0.001$ ) (Model 2). The variable of firm size is not consistent with condition 2 . The significant association between outsourcing and performance (Coefficient $=.172$, $\mathrm{p}<0.001$ ) (Model 3) shows that condition (3) is also satisfied. Nevertheless, the effects of two independent variables (owner/manager knowledge and technical competence) when combined with the outsourcing effect on firm performance (Model 3) indicate mediation effect when compared to the results presented for model 2 . The positive effects of owner/manager knowledge and technical competence decrease $(0.406$ to $0.309,0.625$ to 0.465 , respectively) in strength and remain statistically significant, but the size of the firm negatively associated with outsourcing. Taken together, the above results show that outsourcing does not mediate the relationship between firm size and performance, but it partially mediates the relationship between (a) owner/manager knowledge and firm performance and also (b) technical competence and firm performance. Hence, our hypotheses $5 \mathrm{a}$ and $5 \mathrm{~b}$ are supported, but $5 \mathrm{c}$ is not supported. 


\section{Discussion and conclusions}

In this paper, we have examined the factors that influence a firm's propensity to outsource accounting activities and the benefit that they obtain from outsourcing. Drawing on the resource-based theory (RBT) and transaction cost economics theory (TCE) of the firm, generated and tested on data concerning the utilization of outsourcing by SMEs in the context of Iran.

As hypothesized earlier, outsourcing is positively associated with owner/manager knowledge. Similar to the prior studies that indicated when the SME owners know more about the public sectors' services, they will use higher their services (Audet and St-Jean, 2007) and the use of accounting information system is related to SME owner/manager knowledge of accounting techniques ( Ismail and King, 2007).

(a) The result indicated that technical competence of accountant is positively related to outsourcing. These findings corroborate the previous research conducted by Gooderham et al. (2004), suggested external accountant's competence in delivery of accounting services has a significant effect in using of advisory activities, and by Carey et al., 2006), indicated the technical competence of an external accountant positively associated with outsourcing of internal auditing services.

(b) Our results suggest that the size of the firm by itself is not associated with the outsourcing. This result is in line with Gooderham et al. (2004), found that external accountants' business advice unrelated to the size of the firm and Carey et al. (2006), who revealed that firm size is not associated with the level of internal audit outsourcing, but it runs counter to a few of preceding findings which suggested a broadly positive association between size and outsourcing.

(c) This study has also attempted to shed light on the relationship between outsourcing and firm performance. Specifically, our findings revealed that outsourcing of accounting functions is positively associated with SME performance. Our finding is similar to prior studies that indicated outsourcing (e.g. payroll) had a significant positive influence on firm performance (Gilley et al., 2004; Espino-Rodríguez and Padrón-Robaina, 2004), and the use of advisory services of external accountants is positively associated with SME performance (Bennett and Robson, 1999; Berry et al., 2006; Dyer and Ross, 2008).

(d) In addition, our analysis suggested that outsourcing did not mediate the influence of firm size on SME performance but partially mediated the impact of owner/manager knowledge on firm performance and also technical competence of an accountant on SME performance. The reason is that the relationship between firm size and outsourcing of accounting tasks is clearly a complex one, and the analysis utilized in this study suggests that size often act as proxies for other factors.

Most of the previous works on outsourcing have focused on the areas such as human resource and IT, but a limited research concentrated on the effects of advisory services of accountants on SME performance. Therefore, we have performed a comprehensive study by focusing on the outsourcing of accounting functions using a broader view of SME performance. Therefore, outcomes of this study will also be useful to assist future researchers and SME owner/ managers and professional accountants in Iran, Middle East region and other developing countries to develop comprehensive actions plans to garner the existing (as well as enhance) capabilities of professional accountants in serving the SME community.

\subsection{Limitations and suggestions for future research}

First, the generalizability of this research is limited because all of the enterprises in the sample were manufacturing, generalizing the findings of this research to service sector maynot be suitable. Second, we examined only Iranian SMEs, so our findings may not be generalized to SMEs in other countries. However, the results of this study may require to be interpreted in light of a few constraints. First, this research focused on quantitative method using questionnaire survey, thus future research should employ more in-depth, qualitative methodologies in order to investigate the association between outsourcing and SME performance. Finally, we utilized subjective measures of performance. In future research, it might be useful to examine the relationship between outsourcing and objective measures of performance such as percentage of profits in relation to sales or the rate of growth of either profits or sales within a specific industry.

\section{References}

Audet, J., \& St-Jean, E. (2007). Factors affecting the use of public support services by SME owners: evidence from a periphery region of Canada. Journal of Developmental Entrepreneurship, 12(2), 165-180, doi:10.1142/S1084946707000629, http://dx.doi.org/10.1142/S1084946707000629

Baron, R.M., Kenny, D.A. (1986). The moderator mediator variable distinction in social psychological research: 
conceptual, strategic, and statistical considerations. Journal of Personality and Social Psychology 51 (6), 1173-1182, doi:10.1037/0022-3514.51.6.1173, http://dx.doi.org/10.1037/0022-3514.51.6.1173

Bayati, A., \& Taghavi, A. (2007). The impacts of acquiring ISO 9000 certification on the performance of SMEs in Tehran. The TQM Magazine, 19(2), 140-149, doi:10.1108/09544780710729980, http://dx.doi.org/10.1108/09544780710729980

Bennett, R., \& Robson, P. (1999). The use of external business advice by SMEs in Britain Entrepreneurship and Regional Development 11(2), 155-180. doi:10.1080/089856299283245, http://dx.doi.org/10.1080/089856299283245

Bennett, R., \& Robson, P. (2003). Changing use of external business advice and government support by SMEs in the 1990s. Regional Studies, 37(8), 795-811, doi:10.1080/0034340032000128721, http://dx.doi.org/10.1080/0034340032000128721

Berry, A. J., Sweeting, R., \& Goto, J. (2006). The effect of business advisers on the performance of SMEs. Journal of Small Business and Enterprise Development, 13(1), 33-47, doi:10.1108/14626000610645298, http://dx.doi.org/10.1108/14626000610645298

Blackburn, R., Eadson, W., Lefebvre, R., \& Gans, P. (2006). SMEs, regulation and the role of the accountant (No. 96). London: Certified Accountants Educational Trust.

Breen, J., Sciulli, N., \& Calver, C. (2003). The Role of the External Accountant in Small Firms. Paper presented at the the Small Enterprise Association of Australia and New Zealand 16th Annual Conference, Ballarat, 28 Sept-1 Oct, 2003.

Caldeira, M. M., \& Ward, J. M. (2003). Using resource-based theory to interpret the successful adoption and use of information systems and technology in manufacturing small and medium-sized enterprises. European Journal of

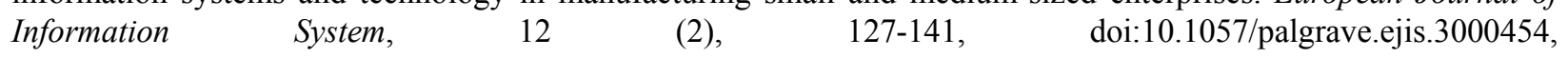
http://dx.doi.org/10.1057/palgrave.ejis.3000454

Carey, P., Simnett, R., \& Tanewski, G. (2005). Providing Business Advice for Small to Medium Enterprises (No. 1-876 874 260). Melbourne: CPA Australia.

Carey, P., Subramaniam, N., \& Ching, K. C. W. (2006). Internal audit outsourcing in Australia. Accounting and Finance 46, 11-30, doi:10.1108/14626000610645298, http://dx.doi.org/10.1108/14626000610645298

Deakins, D., Logan, D., \& Steele, L. (2001). The Financial Management of the Small Enterprise. ACCA Research Report No. 64. London: The Association of Chartered Certified Accountants, Certified Accountants Educational Trust.

Doran, M. (2006). Bean counter or business adviser? An exploratory study of changing times for the accounting practitioner in Ireland. The Irish Accounting Review, 13(1), 23-46, http://www.highbeam.com/doc/1P3-1255755201.html

Doving, E., \& Gooderham, P. N. (2005). Small firm accountancy practices as business advisors: a dynamic capabilities view of the scope of their services (Working paper, No:65/05). Norway, Institute for research in economics and business administration.

Dyer, L. M., \& Ross, C. A. (2008). Seeking advice in a dynamic and complex business environment: Impact on the success of small firms. Journal of Developmental Entrepreneurship, 13(2), 133-149, doi:10.1142/S1084946708000892, http://dx.doi.org/10.1142/S1084946708000892

Espino-Rodríguez, T. F., \& Padrón-Robaina, V. (2004). Outsourcing and its impact on operational objectives and performance: a study of hotels in the Canary Islands. Hospitality Management, 23(287-306), doi:10.1016/j.jhm.2003.11.004, http://dx.doi.org/10.1016/j.ijhm.2003.11.004

Espino-Rodri'guez, T. s. F., Lai, P.-C., \& Baum, T. (2008). Asset specificity in make or buy decisions for service operations An empirical application in the Scottish hotel sector. International Journal of Service Industry Management, 19(1), 111-133, doi:10.1108/09564230810855734, http://dx.doi.org/10.1108/09564230810855734

Everaert, P., Sarens, G., \& Rommel, J. (2006). Outsourcing of Accounting Tasks in SMEs: An extended TCE Model (No. 409).

Everaert, P., Sarens, G., \& Rommel, J. (2007). Sourcing strategy of Belgian SMEs: empirical evidence for the accounting services. Production Planning \& Control, 18(8), 716-725, doi:10.1080/09537280701706195, http://dx.doi.org/10.1080/09537280701706195 
Everaert, P., Sarens, G., \& Rommel, J. (2010). Using Transaction Cost Economics to explain outsourcing of accounting. Small Bus Econ, 35(1), 93-112, doi: 10.1007/s11187-008-9149-3, http://dx.doi.org/10.1007/s11187-008-9149-3

Gilley, K. M., Greer, C. R., \& Rasheed, A. A. (2004). Human resource outsourcing and organizational performance in manufacturing firms. Journal of Business Research 57, 232-240, doi:10.1016/S0148-2963(02)00304-1, http://dx.doi.org/10.1016/S0148-2963(02)00304-1

Gilley, K. M., \& Rasheed, A. (2000). Making more by doing less: an analysis of outsourcing and its effects on firm performance. Journal of Management, 26(4), 763- 790. doi:10.1177/014920630002600408, http://dx.doi.org/10.1177/014920630002600408

Gooderham, P. N., Tobiassen, A., Doving, E., \& Nordhaug, O. (2004). Accountants as sources of business advice for small firms. International Small Business Journal, 22(1), 5-22, doi:10.1177/0266242604039478, http://dx.doi.org/10.1177/0266242604039478

Gunasekaran, A., Marri, H. B., \& Grieve, R. J. (1999). Activity based costing in small and medium enterprises. Computers \& Industrial Engineering 37, 407-411, doi:10.1016/S0360-8352(99)00105-9, http://dx.doi.org/10.1016/S0360-8352(99)00105-9

Hadjimanolis, A. (2000). A resourced-based view of innovativeness in small firms. Tech Anal Strateg Manage, 12(2), 263-292, doi:10.1016/S0148-2963(02)00304-1, http://dx.doi.org/10.1016/S0148-2963(02)00304-1

IFAC. (2006). Micro-Entity Financial Reporting: Perspectives of Preparers and Users (No. information Paper): Small and Medium Enterprises Committee (http://www.ifac.org).

Ismail, N. A., \& King, M. (2005). Firm performance and AIS alignment in Malaysian SMEs. International Journal of Accounting Information Systems, 6 241- 259, doi:10.1016/j.accinf.2005.09.001, http://dx.doi.org/10.1016/j.accinf.2005.09.001

Ismail, N. A., \& King, M. (2007). Factors influencing the alignment of accounting information systems in small and medium sized Malaysian manufacturingirms. Journal of Information Systems and Small Business 1 (1-2), 1-20.

Jayabalan, J., Raman, M., Dorasamy, M., \& Ching, N. K. C. (2009). Outsourcing of Accounting Functions amongst SME Companies in Malaysia: An Exploratory Study. Accountancy Business and the Public Interest, 8(2), 96-114, http://visar.csustan.edu/aaba/Dorasamy2009.pdf

Jiang, B., Frazier, G. V., \& Prater, E. L. (2006). Outsourcing effects on firms' operational performance: An empirical study. International Journal of Operations \& Production Management, 26(12), 1280-1300, doi:10.1108/01443570610710551, http://dx.doi.org/10.1108/01443570610710551

Johnson, S., Webber, D. J., \& Thomas, W. (2007). Which SMEs use external business advice? A multivariate subregional study. Environment and Planning A, 39, 1981 - 1997. doi:10.1068/a38327, http://dx.doi.org/10.1068/a38327

Kamyabi, Y., \& Devi, S. (2011). An Empirical Investigation of Accounting Outsourcing in Iranian SMEs: Transaction Cost Economics and Resource-Based Views. International Journal of Business and Management, 6(3), 81-94, http://ccsenet.org/journal/index.php/ijbm/article/viewFile/9694/6948

Kirby, D. A., Najak.B, \& Greene.F. (1998). Accounting for growth: Ways accountants can add value to small businesses. The Research Board, ICAEW. London.

Leung, P., Raar, J., \& Tangey, G. (2008). Accounting Services and SMEs:An Australian Study (No. 99). Melbourne, Australia: The Association of Chartered Certified Accountants.

Liddicoat, D. L., \& Stringer, D. (2005). Perceptions of Support Services Available in Nelson For Small Medium Enterprises (SMEs) (Working Paper Series No. 4/2005).

Mahmoodzadeh, E., Jalalinia, S., \& Yazdi, F. N. (2009). A business process outsourcing framework based on business process management and knowledge management. Business Process Management Journal, 15(6), 845-864, doi:10.1108/14637150911003748, http://dx.doi.org/10.1108/14637150911003748

Marlow, S., \& Carter, S. (2005). Access to finance: women's enterprise and the role of the accountant (No. 90). London: The Association of Chartered Certified Accountants.

Marriott, N., \& Marriott, P. (2000). Professional accountants and the development of a management accounting service for the small firm: barriers and possibilities. Management Accounting Research, 11, 475-492, doi:10.1006/mare.2000.0142, http://dx.doi.org/10.1108/14637150911003748 
Marriott, N., Marriott, P., Collis, J., Son, D. D., \& (2008). The Accountant and the Provision of Financial Advice to UK Smaller Companies Paper presented at the British Accounting Association Annual Conference 1st-3rd April 2008.

Mashayekhi, B., \& Mashayekh, S. (2008). Development of accounting in Iran. The International Journal of Accounting, 43, 66-86, doi:10.1016/j.intacc.2008.01.004, http://dx.doi.org/10.1016/j.intacc.2008.01.004

McIvor, R., Humphreys, P., McKittrick, A., \& Wall, T. (2009). Performance management and the outsourcing process Lessons from a financial services organisation. International Journal of Operations \& Production Management, 29(10), 1025-1048, doi:10.1108/01443570910993474, http://dx.doi.org/10.1108/01443570910993474

Mirshekary, S., \& Saudagaran, S. M. (2005). Perceptions and characteristics of financial statement users in developing countries: Evidence from Iran. Journal of International Accounting, Auditing and Taxation, 14 33-54, doi:10.1016/j.intaccaudtax.2005.01.001, http://dx.doi.org/10.1016/j.intaccaudtax.2005.01.001

Mohan-Neill, S. I. (1995). The Influence of Firm's Age and Size on Its Environmental Scanning Activities. Journal of Small Business Management, 33(4), 10-21, http://www.questia.com/googleScholar.qst?docId=5000368272

Salehi, M., \& Azary, Z. (2008). Fraud Detection and Audit Expectation Gap: Empirical Evidence from Iranian Bankers. International Journal of Business and Management, 3(10), http://ccsenet.org/journal/index.php/ijbm/article/view/1043

Sarapaivanich, N., \& Kotey, B. (2006). The effect of financial information quality on ability to access external funds and performance of SMEs in Thailand. Journal of Enterprising Culture, 14(3), 219-239, http://ideas.repec.org/a/wsi/jecxxx/v14y2006i03p219-239.html

Shang, J.-K., Hung, W.-T., \& Wan, F.-C. (2008). Service outsourcing and hotel performance: three-stage DEA analysis. Applied Economics Letters, 15, 1053-1057. doi:10.1080/13504850600993523, http://dx.doi.org/ $10.1080 / 13504850600993523$

Sian, S., \& Roberts, C. (2009). UK small owner-managed businesses: accounting and financial reporting needs. Journal of small Business and Enterprise Development, 16(2), 289-305, doi:10.1108/14626000910956065, http://dx.doi.org/10.1108/14626000910956065

Stanger, A. M. J. (2004). Gender-comparative use of small business training and assistance: A literature review. Education \& Training, 46(8/9), 464, doi:10.1108/00400910410569588, http://dx.doi.org/10.1108/00400910410569588

Stratman, J. K. (2008). Facilitating offshoring with enterprise technologies: reducing operational friction in the governance and production of services. Journal of Operations Management, 26(2), 275-287, doi:10.1016/j.jom.2007.02.006, http://dx.doi.org/10.1016/j.jom.2007.02.006

UNIDO. The United Nations Industrial Development Organization (2003). To enhance the contribution of an efficient and competitive small and medium-sized enterprise sector to industrial and economic development in the Islamic republic of Iran (Publication. Retrieved http://www.unido.org/fileadmin/import/18229_AbsFinal.pdf:

Watson. (2003). The potential impact of accessing advice on SME failure rates. Paper presented at the Small Enterprise Association of Australia and New Zealand 16th Annual Conference, Ballarat, 28 Sept-1 Oct, 2003.

Table1. Descriptive statistics and correlations

\begin{tabular}{|l|l|l|l|l|l|l|l|}
\hline Variables & Mean & S.D. & $\mathbf{1}$ & $\mathbf{2}$ & $\mathbf{3}$ & $\mathbf{4}$ & $\mathbf{5}$ \\
\hline 1. Performance & 72.84 & 15.69 & 1 & & & & \\
\hline 2.Outsourcing & 62.89 & 22.69 & $.464^{* *}$ & 1 & & & \\
\hline 3.Owner/ manager knowledge & 41.90 & 13.97 & $.427^{* *}$ & $.389^{* *}$ & 1 & & \\
\hline 4. Technical Competence & 31.02 & 7.57 & $.439^{* *}$ & $.381^{* *}$ & $.399^{* *}$ & 1 & \\
\hline 5. Firm Size (number of employees) & 2.80 & 1.43 & $-.137^{* *}$ & .006 & $.148^{* *}$ & .028 & 1 \\
\hline
\end{tabular}

**correlation is significant at the 0.01 level (2-tailed) 
Table 2. Result of regression analyses for direct effects

\begin{tabular}{|l|c|c|}
\hline \multirow{2}{*}{ Variables } & $\frac{\text { Outsourcing }}{\text { Model 1 }}$ & $\begin{array}{c}\text { Firm performance } \\
\text { Model 2 }\end{array}$ \\
\cline { 2 - 3 } & Coefficient(S.E) & - \\
\hline O/M knowledge & $.529(.078)^{* * *}$ & - \\
\hline Size & $.754(.137)^{* * *}$ & - \\
\hline Outsourcing & $-.489(.697)$ & $.317(.029)^{* * *}$ \\
\hline Constant & - & $52.8(1.911)$ \\
\hline R2 & $18.508(4.616)$ & .215 \\
\hline Adjusted R2 & .234 & .214 \\
\hline F-value & .229 & 122.697 \\
\hline
\end{tabular}

Note: $\mathrm{n}=658$. Unstandardized coefficients reported. Numbers in parentheses are Standard Errors (S.E). Significance at $* * * \mathrm{p}<0.001$

Table 3. Result of regression analyses for mediation effects

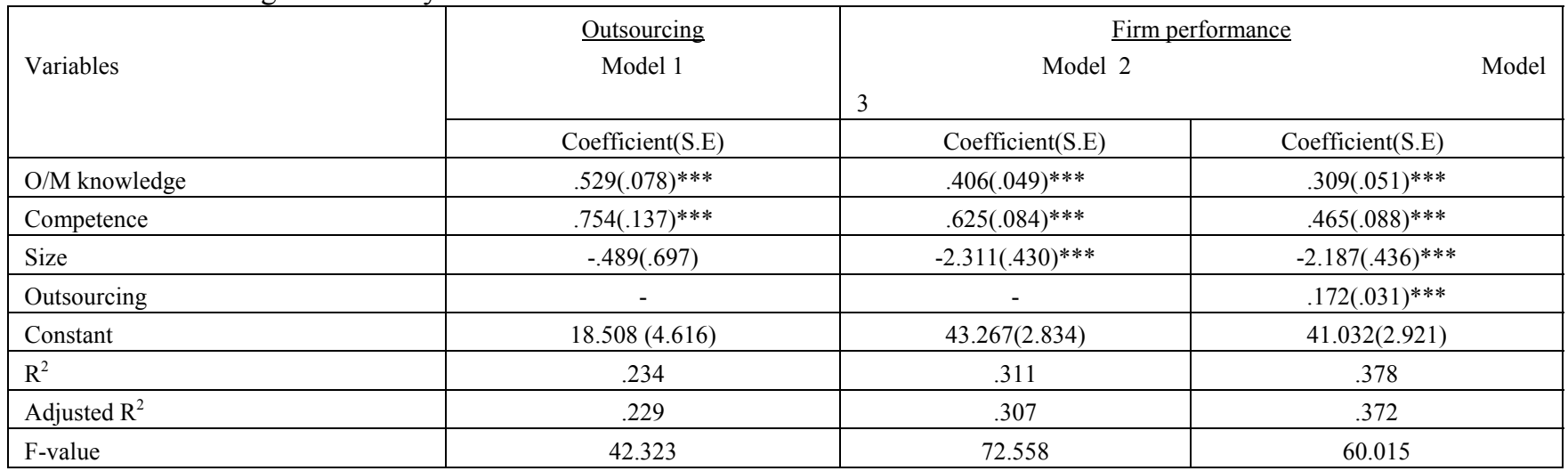

Note: $\mathrm{n}=658$. Unstandardized coefficients reported. Numbers in parentheses are Standard Errors (S.E). Significance at $* * * \mathrm{p}<0.001$

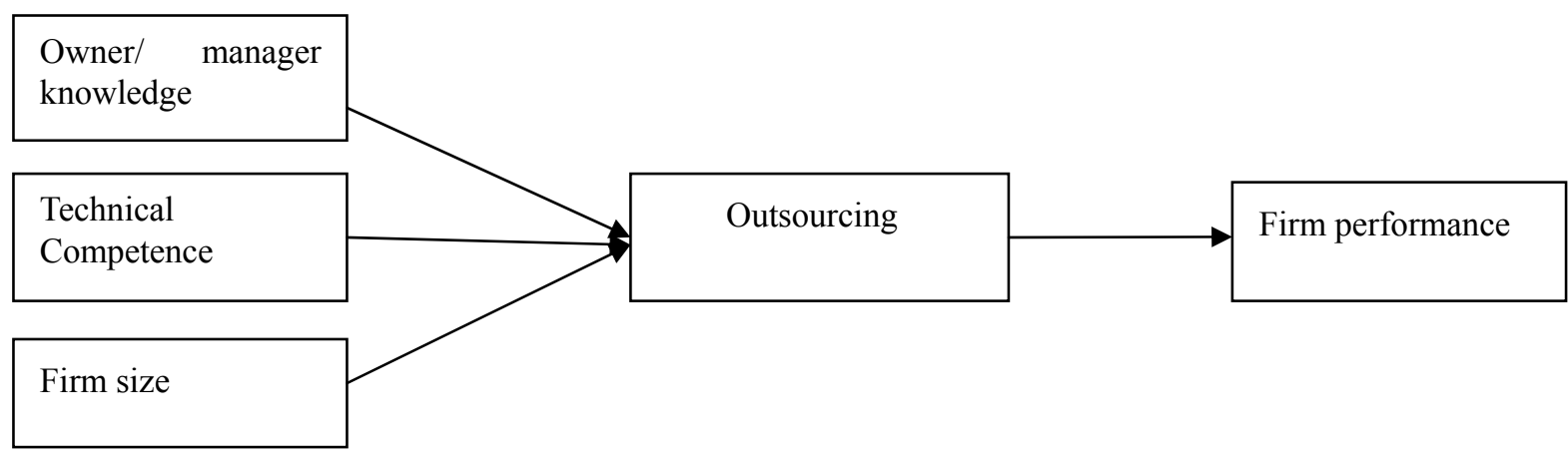

Figure1. Theoretical framework 